Journal MULTICULTURAL of Islamic Edication Program Magister Pendidikan Agama Islam Multikultural Universitas Yudharta Pasuruan

P-ISSN (Cetak) : 2598-506X

E-ISSN (Online) : 2598-5957

\title{
NILAI-NILAI TOLERANSI ANTAR SESAMA DAN ANTAR UMAT BERAGAMA (Studi Pandangan KH. Sholeh Bahruddin)
}

\author{
${ }^{1}$ Kalimatul Zuhroh, ${ }^{2}$ M. Anang Sholihuddin \\ ${ }^{1}$ zahrah@gmail.com, ${ }^{2}$ anangsholikhudin@yudharta.ac.id \\ ${ }^{1}$ SMP Bhinneka Tunggal Ika Sengonagung, \\ ${ }^{2}$ Universitas Yudharta Pasuruan
}

\begin{abstract}
This study aims to find out about (1) tolerance values, (2) the view of $\mathrm{KH}$. Sholeh Bahruddin about the values of tolerance between one another and between religious groups. (3) Reasons for KH. Sholeh Bahruddin has an important view on tolerance between people and between religious communities. The results of the study show that: Tolerance between people includes tolerance of fellow humans and tolerance of other God beings such as animals and plants. Whereas inter-religious tolerance is based on: each religion is the responsibility of followers of the religion itself and has a form of worship (ritual) with its own system and method which is interpreted (charged) and becomes the responsibility of the person who embraces it on that basis, tolerance in social life between religious communities is not tolerance in religious matters, but rather the manifestation of the religious attitude of followers of a religion in the association of life between people who are not religious, in social issues or general welfare.
\end{abstract}

Keywords: Tolerance Values, Between Religious People

Abstrak: Penelitian ini bertujuan untuk mengetahui tentang (1) nilai-nilai toleransi, (2) pandangan KH. Sholeh Bahruddin tentang nilai-nilai toleransi antar sesama dan antar umat beragama, (3) Alasan KH. Sholeh Bahruddin memiliki pandangan penting tentang toleransi antar sesama dan antar umat beragama. Hasil penelitian menunjukkan bahwa: Toleransi antar sesama meliputi toleransi sesama manusia dan toleransi terhadap makhluk Tuhan lainnya seperti hewan dan tumbuhan. Sedangkan toleransi antar umat beragama didasarkan kepada: setiap agama menjadi tanggung jawab 
pemeluk agama itu sendiri dan mempunyai bentuk ibadat (ritual) dengan sistem dan cara tersendiri yang ditaklifkan (dibebankan) serta menjadi tanggung jawab orang yang memeluknya atas dasar itu, maka toleransi dalam pergaulan hidup antar umat beragama bukanlah toleransi dalam masalah keagamaan, melainkan perwujudan sikap keberagamaan pemeluk suatu agama dalam pergaulan hidup antara orang yang tidak seagama, dalam masalah-masalah kemasyarakatan atau kemaslahatan umum.

Kata Kunci : Nilai-Nilai Toleransi, Antar Umat Beragama,

\section{PENDAHULUAN}

Terkait dengan keanekaragaman bangsa Indonesia mempunyai semboyan yang sangat adil dan demokratis. "Bhinneka Tunggal Ika". Semboyan ini memiliki pengertian bahwa proporsional, dengan menerima perbedaan, mengakui, dan menghargainya.

Sebenarnya, keberagaman dalam suatu komunitas bisa memberikan energi positif apabila digunakan sebagai modal untuk bisa bersama membangun bangsa dalam hubungan yang saling memberi dan menerima, dan sebaliknya apabila keberagaman masih dibingkai oleh penafsiran yang bersumber pada sebuah simbol yang mengikat atau menekan dimana sarat akan prasangka, kecurigaan, bias, dan reduksi terhadap kelompok di luar dirinya, maka ia hanya akan menjadi bom penghancur struktur dan pilar kebangsaan. ${ }^{1}$

Salah satu tempat mempelajari keberagaman yang paling mendasar adalah di pesantren karena di dalam pesantren terdapat berbagai macam perbedaan misalnya, berbeda latar belakang keluarga, wilayah, status sosial, dan pendapat maupun pemikiran. Pondok Pesantren merupakan institusi sosial keagamaan yang menjadi wahana pendidikan bagi umat Islam yang ingin mendalami ilmu-ilmu keagamaan. ${ }^{2}$ Secara umum, pesantren memiliki tipologi yang sama, yaitu sebuah lembaga yang dipimpin dan diasuh oleh kiai satu kompleks yang bercirikan adanya masjid atau surau sebagai pusat pengajaran dan asrama sebagai tempat tinggal santri dengan "kitab kuning" sebagai kitab pegangan.

\footnotetext{
${ }^{1}$ Masdar Hilmy, Menggagas Paradigma Pendidikan Berbasis Multikulturalisme. Jurnal Ulumuna,Volume VII Edisi 12 Nomor 2 Juli Desember 2003: 333

${ }^{2}$ Rafiq Zainul Mun'im, A. "Peran Pesantren dalam Education For All di Era Globai", 2009, dalam https://www:researchgate.net di akses tanggal 23 Juli 2017.
} 
Sosok seorang guru atau pemimpin pesantren juga sangat mempengaruhi, karena apapun yang didawuhkan atau diperintahkan sudah pasti ditaati dan dilakukan. Sebagaimana di Pondok Pesantren Ngalah Sengonagung Purwosari Pasuruan yang diasuh oleh KH.M. Sholeh Bahruddin. Beliau adalah sosok pemimpin yang baik menurut peneliti karena beliau sangat luas, luwes, dan juga cinta tanah air. Hal ini dibuktikan dengan selain beliau adalah mursyid Tariqoh tidak hanya memikirkan kehidupan akhirat saja dalam artian fokus terhadap hubungan vertikal (ibadah) kepada Allah tetapi juga tetap memperhatikan hubungan muamalah, salah satunya yakni turut menjaga keutuhan Negara Kesatuan Republik Indonesia (NKRI). Hal ini dibuktikan juga dengan syi'ir yang berbunyi :" Kyai sholeh santri kendil mung diniyah \# tapi mikir nasib bongso Indonesia, Sing maksude ojo congkrah tunggal bongso \# ojo nganti lepas songko Pancasila”. 3

Dalam setiap momen dan waktu apapun KH. Sholeh Bahruddin selalu mengingatkan kepada santri, jamaah, dan juga masyarakat untuk selalu mencintai Indonesia dan turut menjaga keutuhan NKRI sesuai kemampuan yang dimiliki masing-masing. Seperti dalam acara seminar, wisuda sekolah formal, maupun pada kegiatan yang diadakan di pondok misalnya pengajian Senenan, Selosoan, dan Maleman yang diikuti oleh semua kalangan masyarakat baik wilayah Pasuruan ataupun luar Pasuruan.

Sering di pondok Ngalah terselenggara acara yang melibatkan berbagai agama seperti acara Kolokium Antar Umat Beragama pada tahun 2004 yang mana berbagai tokoh agama bertemu dan membahas kerukunan antar umat beragama, seminar kebangsaan, dan kemarin pada tanggal 21 Maret 2017 di Universitas Yudharta juga ada acara dialog antar umat beragama. ${ }^{4}$

Jika dilihat dari sikap dan dawuh yang ditunjukkan KH. Sholeh Bahruddin tentang cinta tanah air dan cinta pada sesama. Sikap tersebut termasuk salah satu contoh sikap yang mencerminkan nilai-nilai multikultural. Nilai multikultural yang lain misalnya nilai toleransi, nilai kerukunan, dan nilai kesetaraan. ${ }^{5}$ Tetapi dalam penelitian ini, peneliti bertujuan mencari dan menemukan tentang nilai-nilai toleransi yang meliputi : mengakui hak orang lain, menghormati keyakinan orang lain, agree in

\footnotetext{
${ }^{3}$ Ahmad Muhtadin.2010."Mutiara Nasihat (Romo KH.M.Sholeh Bahruddin untuk Santrisantrinya)".

${ }^{4}$ Khoiron. Dokumen foto kegiatan Pondok Pesantren Ngalah. Diperoleh 15 April 2019

${ }^{5}$ Hasan Basri. 2017. Penanaman Nilai-Nilai Multikultural Melalui Pendidikan Agama Islam di SMK Triatma Jaya . Semarang: 11-13
} 
44 :.: Nilai- Nilai Toleransi Antar Sesama Dan Antar Umat Beragama (Studi

Pandangan KH. Sholeh Bahruddin)

disagreement (setuju dalam perbedaan), dan jiwa falsafah Pancasila KH. Sholeh Bahruddin.

Karena istilah multikultural sangat luas pembahasannya dan banyak nilai-nilai yang terkandung di dalamnya yang patut difahami oleh masyarakat terutama masyarakat awam, maka peneliti disini akan mengerucutkan mengkaji tentang Nilai-nilai Toleransi Antar Sesama dan Antar Umat Beragama (Studi Pandangan KH. Sholeh Bahruddin)

\section{PEMBAHASAN}

Dalam pengertian toleransi secara umum menyatakan doktrin pluralisme mengakui kebenaran agama lain, Islam hanya mengakui Islam yang paling benar di sisi Allah SWT namun Islam menjunjung tinggi toleransi. Bahkan toleransi (tasamuh) merupakan karakteristik Islam sendiri sebagai alHanifiyah as-Samhah. ${ }^{6}$ Dalam komunikasi manusia, tasamuh dapat dibagi sebagai berikut:

1) Tasamuh antara sesama muslim seperti: saling tolong-menolong saling menghargai, saling menyayangi, menjauhkan saling curiga-mencurigai.

2) Tasamuh terhadap non muslim saling menghargai hak-hak mereka selaku manusia dan selaku anggota msyarakat dalam suatu negara. ${ }^{7}$

Menurut demokrasi Pancasila, toleransi dikatakan sebagai suatu pandangan yang mengakui the right of self determination, yang artinya hak menentukan sendiri nasib pribadi masing-masing. Tentu saja di dalam menentukan hak itu seseorang tidak harus melanggar hak-hak orang lain. Toleransi diwujudkan dalam dua sikap, yaitu membiarkan eksis terhadap sesuatu, tanpa memusuhi, dengan menghormati keyakinan lain tanpa berpretensi menyalahkan, kedua bekerjasama dalam bidang tertentu.

Toleransi juga berarti sikap atau sifat menenggang berupa menghargai serta membolehkan suatu pendirian, pendapat, pandangan, kepercayaan maupun yang lainnya yang berbeda dengan pendirian sendiri. ${ }^{8}$ Sedangkan menurut Dewan Ensiklopedia Indonesia toleransi dalam aspek sosial, politik, merupakan suatu sikap membiarkan orang untuk mempunyai suatu keyakinan yang berbeda. ${ }^{9}$

\footnotetext{
${ }^{6}$ Adib Fuadi Nuriz,2015.Problem Pluralisme Agama dan Dampaknya terhadap Kehidupan Sosial Keagamaan . Ponorogo: Center for Islamic and Occidental Study: 107

${ }^{7}$ Amir, Samsul, Munir, 2009, Ilmu Dakwah,( Jakarta: amzah): 142

${ }^{8}$ W.J.S Poerwadarminto, 1986, Kamus Umum Bahasa Indonesia, Balai Pustaka, Jakarta: 1084

${ }^{9}$ Dewan Ensiklopedia Indonesia, Ensiklopedia Indonesia Jilid 6, Ikhtiar Baru Van Hoeve, t.th: 3588
} 
Istilah toleransi diartikan sebagai pemberian kebebasan kepada sesama manusia atau sesama warga masyarakat untuk menjalankan keyakinan, atau mengatur kehidupannya dan menentukan nasibnya masingmasing, selama di dalam menjalankan dan menentukan sikapnya itu tidak melanggar dan tidak bertentangan dengan syarat-syarat azas terciptanya ketertiban dan perdamaian dalam masyarakat. ${ }^{10}$

Menurut pendapat Walzer toleransi harus mampu membentuk kemungkinan-kemungkinan sikap, antara lain:

1. Sikap untuk menerima perbedaan

2. Mengubah penyeragaman menjadi keragaman

3. Mengakui hak orang lain

4. Menghargai eksistensi orang lain

5. Mendukung secara antusias terhadap perbedaan budaya dan keragaman ciptaan Tuhan YME ${ }^{11}$

Dari beberapa pengertian di atas penulis menyimpulkan bahwa toleransi adalah suatu sikap atau sifat dari seseorang untuk membiarkan kebebasan kepada orang lain serta memberikan kebenaran atas perbedaan tersebut sebagai pengakuan hak-hak asasi manusia.

Pelaksanaan sikap toleransi ini harus didasari sikap kelapangan dada terhadap orang lain dengan memperhatikan prinsip-prinsip yang dipegang sendiri, yakni tanpa mengorbankan prinsip-prinsip tersebut. ${ }^{12}$

Di dalam memaknai toleransi terdapat dua penafsiran. Pertama, penafsiran yang bersifat negatif yang menyatakan bahwa toleransi itu cukup mensyaratkan adanya sikap membiarkan dan tidak menyakiti orang atau kelompok lain baik yang berbeda maupun yang sama. Sedangkan yang kedua adalah yang bersifat positif yaitu menyatakan bahwa harus adanya bantuan dan dukungan terhadap keberadaan orang lain atau kelompok lain ${ }^{13}$

Toleransi merupakan kemampuan untuk dapat menghormati sifat-sifat dasar, keyakinan, dan perilaku yang dimiliki orang lain. Selain itu, toleransi juga bisa dipahami sebagai sifat atau sikap menghargai, membiarkan atau membolehkan pendirian (pandangan, pendapat, kepercayaan kebiasaan,

${ }^{10}$ Bashori Mulyono. 2010. Ilmu Perbandingan Agama, Jawa Barat: Pustaka Sayid Sabiq: 114-115

11 Zuhairi Misrawi, Al-Qur'an Kitab Toleransi, Inklusivisme, Prulaisme, dan Multikulturalisme, (Jakarta: Fitrah, 2010): 10

${ }^{12}$ H.M. Daud Ali, dkk., 1989, Islam Untuk Disiplin Ilmu Hukum Sosial dan Politik, Bulan (Jakarta:Bintang): 80.

13 Masykuri Abdullah, Pluralisme Agama dan Kerukunan dalam Keragaman, (Jakarta:Penerbit Buku Kompas, 2001): 13 
46 :.: Nilai- Nilai Toleransi Antar Sesama Dan Antar Umat Beragama (Studi

Pandangan KH. Sholeh Bahruddin)

kelakuan dan sebagainya) orang lain yang bertentangan dengan kita. Atau dengan kata lain, hakikat toleransi adalah hidup berdampingan secara damai (peaceful coexistence) dan saling menghargai di antara keragaman (mutual respect $)^{14}$

Namun perlu digaris bawahi di sini, toleransi dalam hal keagamaan bukan dimaknai sebagai sikap menerima ajaran agama-agama lain, seperti dalam hal kepercayaan. Melainkan perwujudan sikap keberagamaan pemeluk satu agama dalam pergaulan hidup dengan orang yang tidak seagama. Sebagai umat yang beragama, diharapkan dapat membangun sebuah tradisi wacana keagamaan yang menghargai keberadaan agama lain, dan bisa menghadirkan wacana agama yang tolerans dan transformatif. ${ }^{15}$ Sehingga dapat dipertegas bahwa toleransi bukanlah dimaknai sebagai mengakui kebenaran agama mereka, melainkan pengakuan terhadap agama mereka dalam realitas kehidupan bermasyarakat. Selain itu, toleransi juga bukan berarti sikap kopromi atau kerjasama sama dalam keyakinan dan ibadah ${ }^{16}$

\section{Toleransi sesama manusia}

Toleransi sesama manusia dapat diartikan suatu sikap atau sifat dari seseorang untuk membiarkan kebebasan kepada orang lain serta memberikan kebenaran atas perbedaan tersebut sebagai pengakuan hak-hak asasi manusia. Salah satunya adalah hak untuk hidup karena setiap orang mempunyai hak hidupnya masing-masing. KH. Sholeh Bahruddin juga membenci orang yang tega membunuh orang lain hal ini dapat disimpulkan dari beliau yang pernah bercerita bahwasannya ada salah satu sahabat yang bernama Abdurrahman bin Muljam yang membunuh sepupu Nabi Muhammad yaitu Ali bin Abi Thalib.

Diceritakan oleh Syamsudin ad-Dzahabi (748 H) dalam kitabnya tarikhul islam wa wafayati masyahiril a'lam bahwa Abdurrahman bin Muljam merupakan sosok ahli al-Qur'an dan fikih. Selain itu, ia merupakan orang yang gemar ibadah. Meskipun dia ahli Al-Qur'an, ahli fiqh, dan ahli ibadah tetapi dia tidak berhak untuk mengambil hak hidup sahabat Ali bin Abi Thalib karena seseorang tidak kuasa atau melenyapkan hidup seseorang

\footnotetext{
14 Moh. Yamin dan Vivi Aulia, Meretas Pendidikan Toleransi; Pluralisme dan Multikulturalisme Sebuah Keniscayaan Peradaban, (Malang: Madani Media, 2011): 6

${ }^{15}$ Nurcholis Madjid. Pluralitas Agama; Kerukunan dalam Keragaman, (Jakarta: Kompas Media Nusantara, 2001): 39

16 Ahmad Muzakkil Anam . 2016, Penanaman Nilai-Nilai Pendidikan Multikultural di Perguruan Tinggi (Studi Kasus di Universitas Islam Malang): 48
} 
tanpa kehendak Allah sebagaimana termaktub dalam Al-Qur'an surat Al-Hijr ayat $23 .{ }^{17}$

Karena perbuatannya itulah Abdurrahman bin Muljam tidak diangkat sebagai seorang pemimpin tetapi dia di hukum yang sepadan dengan perbuatannya yaitu hukum qishas. Dari peristiwa inilah ditetapkannnya hukum qishas dalam Al-Qur'an. Perintah ini termaktub dalam surat AlMaidah ayat 32 yang dijelaskan bahwa ayat diatas mempersamakan antara pembunuhan terhadap seorang manusia yang tidak berdosa dan membunuh semua manusia, dan menyelamatkannya sama dengan menyelamatkan semua manusia. Peraturan baik apapun yang ditetapkan oleh Allah, pada hakekatnya adalah untuk kemaslahatan masyarakat manusia. kalau kita menyebut kata masyarakat, maka kita semua tahu bahwa ia adalah kumpulan dari manusia. ${ }^{18}$

Ayat diatas sekaligus menunjukkan bahwa dalam pandangan AlQur'an, semua manusia apapun ras, keturunan, dan agamanya adalah sama dari segi kemanusiaan karena jiwa manusia adalah haram dibunuh, tidak boleh disakiti dan segala upaya harus dilakukan untuk melindunginya, kecuali berdasarkan hukum, maka hukum Qishas wajib untuknya.

Hak lain yang dimiliki setiap manusia adalah hak untuk beragama. Di Indonesia yang terdiri dari berbagai macam agama yakni Islam, Kristen, Katolik, Hindu, Budha,dan Khonghucu. Maka setiap warna negara berhak meyakini agamanya masing-masing dan menghormati keyakinan agama lain. Contoh kecil KH. Sholeh Bahruddin sebagai pendiri sekaligus pengasuh Pondok Pesantren Ngalah dan pendiri satu-satunya Universitas yang ada di Pasuruan saat ini yaitu Universitas Yudharta Pasuruan. Beliau memberikan kebebasan kepada siapapun untuk mengajar ataupun belajar di kampus tersebut tanpa membedakan status agama. Ada beberapa dosen dan mahasiswa Kristen yang mengajar dan belajar di kampus ini, diperbolehkan meskipun dalam lingkungan Pondok Pesantren. Apapun agamanya mereka berhak untuk mendapatkan pendidikan yang mereka inginkan.

Dalam hak menentukan pilihan KH.Sholeh Bahruddin juga memberikan kebebasan kepada santri, jama'ah, maupun masyarakat untuk memilih pilihan masing-masing meskipun beliau dan keluarga memilih untuk bersikap netral atau tidak memihak siapapun. Dalam pesta demokrasi misalnya pemilihan Presiden atau DPRD kepada santri, jama'ah, dan masyarakat untuk memilih pilihan mereka sesuai dengan hati nurani, tidak

\footnotetext{
17 "Dan sesungguhnya benar-benar Kami-lah yang menghidupkan dan mematikan dan Kami (pulalah) yang mewarisi"

${ }^{18}$ Quraish Shihab,2012, Tafsir Al-Misbah, Jakarta: Darus Sunnah Press: 101-102
} 
48 :.: Nilai- Nilai Toleransi Antar Sesama Dan Antar Umat Beragama (Studi

Pandangan KH. Sholeh Bahruddin)

memaksa untuk mengikuti pilihan beliau karena dengan bersikap netral beliau berharap tidak ada perpecahan atau pertengkaran antara satu dengan yang lain. Pesta demokrasi bisa terlaksana dengan aman dan damai.

Selain tidak memaksakan hak orang lain kita harus bisa menghormati orang lain. Salah satu cara untuk menumbuhkan rasa menghormati orang lain adalah dengan saling tolong menolong. Dan kebesaran sifat tolong menolong dapat dilihat dalam firman Allah Alquran surat Al-Maidah ayat 2. Dalam menolong orang lain tidak boleh membeda-bedakan dalam hal apapun. Menurut KH. Sholeh Bahruddin agar kita bisa menghormati orang lain kita harus bisa memasyarakat tidak hanya dilingkup yang kecil saja agar bisa menerima dan menghormati sebanyak-banyaknya perbedaan. Tetapi hal tersebut tidaklah mudah pasti ada hal-hal yang akan mengganggu misalnya ketika kita berbuat baik ada saja yang tidak suka, ada fitnah atau adu domba. Dan hal itu harus dihadapi dengan penuh kesabaran.

Sebagai Warga Negara Indonesia (WNI) yang baik dan cinta terhadap Negara, KH. Sholeh Bahruddin sangat menjunjung tinggi Pancasila dan mengamalkannya. Karena menurut beliau jika kita mengamalkan Pancasila maka kita juga mengamalkan ajaran agama Islam yang penuh dengan rahmat, asalkan punya sifat Rahmatan lil 'alamin itu sama saja dengan Pancasila. Kalau menurut Pancasila itu merujuk ke Mitsaqul Madinah ${ }^{19}$. Makanya NU itu tidak punya kamus untuk mendirikan Negara Islam. Tidak ada kamusnya, yang ada hanya Pancasila.

Bhinneka Tunggal Ika semboyan Negara Indonesia yang artinya berbeda-beda tetapi tetap satu jua. Negara Indonesia yang terdiri dari ribuan pulau, bermacam-macam suku, seni, budaya, dan bahasa. Tentunya sangat rentan menimbulkan berbagai macam konflik yang nantinya bisa memecah belah Negara Kesatuan Republik Indonesia (NKRI ) bahkan sampai ada segolongan orang yang mengiginkan Indonesia menjadi Negara Islam dan KH. Sholeh Bahruddin sangat menentang dan membenci hal tersebut. Dengan alasan: pertama, Pancasila itu sudah sesuai dengan Al-Qur'an; kedua, Rasulullah sendiri tidak pernah membentuk sistem Negara Islam (baca: Piagam Madinah); ketiga, Golongan atau kelompok tersebut dinilai tidak menghargai bahkan menghianati para pejuang kemerdekaan bangsa Indonesia, Berusaha memecah belah rakyat Indonesiabahkan berusaha menghancurkan bangunan Negara Kesatuan Republik Indonesia (NKRI), Akan terjadi pergeseran tatanan nilai-nilai tradisi atau kultur Islam ala NU.

${ }^{19}$ Lihat isi Piagam Madinah 
Dalam melakukan sesuatu harus ada dasar yang kuat. Begitu juga dengan suatu Negara sudah pasti mempunyai dasar yang dijadikan pedoman dalam menjalankan peraturan maupaun pemerintahan. Seperti telah ditetapkan bahwa dasar Negara Indonesia Pancasila dan Undang-Undang Dasar (UUD) 1945. Dalam mendirikan, membangun serta mengembangkan yayasan Darut Taqwa KH. Sholeh Bahruddin menetapkan bahwasannya azas Darut Taqwa ada tiga yaitu: Pancasila, UUD 45, dan Ahlussunnah Wal Jama'ah.

Negara Indonesia akan aman dan damai jika tidak ada pertengkaran, tidak ada salah satu pihak yang saling mengadu domba, tidak ada salah satu pihak ingin menguasai. Hal ini tidak bisa tentunya tidak lepas dari adanya sifat saling menghormati perbedaan, menghargai keyakinan orang lain, menghargai hak orang lain, dan saling tolong menolong antar sesama. Semua itu harus disesuaikan dengan tugas dan porsinya masing-masing. Beliau mendukung dan memberikan kesempatan kepada santri untuk menjadi aparatur Negara dan juga andil dalam pesta demokrasi. Sedangkan beliau tetap pada tugas beliau sebagai seorang ulama tetapi yang sangat mencitai NKRI. Beliau selalu mengingatkan bahwa NU sejak lahir tidak pernah benturan dengan pemerintah, tidak pernah benturan dengan TNI/POLRI, tidak pernah bennturan dengan pedagang atau pengusaha dikarenakan sama-sama tiang agama.

Agama dan Negara tidak dapat berdiri tegak kecuali dengan 4 pilar: Ulama': Contoh Kyai (Tokoh Agama) yang bertugas untuk membangun SDM dibidang keilmuan / membangun jiwa

1. Umaro': Contoh pak lurah, camat, bupati, gubernur, presiden dan menterinya yang bertugas membangun fisik

2. Huzat : contoh TNI/POLRI yang bertugas dibidang keamanan dan penegak hukum

3. Ahlul Kasbi :contoh pengusaha, petani, pedagang yang bertugas dibidang perekonomian $^{20}$

Salah satu bentuk toleransi sesama manusia yang sangat jelas dan mencolok adalah contoh sikap seperti menghormati dan menghargai orang lain baik itu berbeda dalam berpendapat, berbeda keyakinan, berbeda suku, bahasa, baik muslim maupun non muslim. Toleransi yang dipraktikkan oleh KH. Sholeh Bahruddin tidak hanya pada sesama muslim tetapi juga pada non muslim karena memang beliau menganggap mereka semua itu saudara.

${ }^{20}$ KH. Sholeh Bahruddin. Pengajian maleman (malam 23). 27 Mei 2019 
50 :.: Nilai- Nilai Toleransi Antar Sesama Dan Antar Umat Beragama (Studi

Pandangan KH. Sholeh Bahruddin)

Dalam hidup bersosial dengan masyarakat beliau tidak membeda-bedakan, baik itu muslim atau non muslim, baik itu orang Jawa atau Madura harus toleran karena sebangsa, setanah air, dan satu bahasa sama dengan isi Sumpah Palapa.

\section{Toleransi terhadap makhluk Tuhan lainnya}

Toleransi kepada makhluk hidup lainnya disini yang dimaksud adalah tentang bagaimana sikap atau cara kita menghargai kebebasan hewan ataupun tumbuhan untuk tetap hidup dan juga lingkungan sekitar yang terjaga kebersihannya. KH. Sholeh Bahruddin penyayang binatang, menyukai kerindangan, dan sangat menjaga lingkungan hidup. Contohnya jika beliau mempunyai binatang peliharaan selalu dijaga dan dirawat dengan baik, tidak lupa memberikan makanan, membersihkan tempat tinggal binatang tersebut. Meskipun tidak langsung turun tangan merawatnya tetapi beliau akan mempercayakan kepada santri yang diamanahinya. Baik hewan maupun tumbuhan menurut beliau semua adalah makhluk hidup yang mempunyai hak untuk hidup dan berkembang, maka harus menghargai kehidupan mereka dengan tidak mengganggu, merusak, ataupun membunuh selama tidak mengganggu kehidupan kita.

\section{Toleransi Antar Umat Beragama}

Toleransi beragama mempunyai arti sikap lapang dada seseorang untuk menghormati dan membiarkan pemeluk agama untuk melaksanakan ibadah menurut ajaran dan ketentuan agama masing-masing yang diyakini, tanpa ada yang mengganggu atau memaksakan baik dari orang lain maupun dari keluarganya sekalipun.

Keyakinan seseorang biasanya berdasarkan kepercayaan yang sudah tertanam didalam hati dan tidak akan mudah untuk dirubah dan dipengaruhi karena keyakinan itu adalah murni dari pribadi masing-masing terlebih lagi tentang keyakinan terhadap Tuhan maka kita menghormati keyakinan orang lain dalam hal apapun. Keyakinan dibidang agama misalnya, kita harus bisa meyakini agama kita masing masing ,jangan sampai terjadi saling mengejek dengan berkata bahwa agama kita yang paling benar. Perbedaan tersebut seharusnya kita jadikan dasar untuk bisa saling menghormati. Sebagaimana dawuh beliau "tetap bersikap saling menghormati meskipun muslim atau non muslim"

Islam tidak melarang untuk membantu dan berhubungan baik dengan pemeluk agama lain dalam bentuk apapun, selama tidak berkaitan dengan masalah aqidah dan ibadah mahdhah (ibadah wajib), seperti shalat, puasa, 
haji, dan sebagainya. Konsep seperti ini telah dicontohkan oleh Rasulullah Saw bagaimana berkomunikasi secara baik dengan orang-orang atau umat non-Muslim.

Hal ini dibuktikan dengan dawuh beliau juga pada pengajian tafsir sebagai berikut: "Metode berjuangnya Romo Yai Sholeh dari carat ke purwosari dengan metode nguwong'no wong (menghormati orang), siapa saja biar itu orang muslim/non muslim (yang khusu/bluduk, yang qorik/korak, yang santri /guru/ mahasiswa/ dosen) semua itu di hormati sama. Itulah metode nguwong'no wong (memanusiakan manusia) ${ }^{21}$.

Karenanya suatu keyakinan tidak dapat dipaksakan ${ }^{22}$, maka langkah yang baik agar dapat hidup bersama dalam perbedaan yaitu dengan menghormati keyakinan orang lain. Islam telah mengatur hidup umatnya dengan tidak memaksakan kehendak orang lain dalam hal keyakinan atau agama. Sebagai dasar adalah orang lain boleh mengikuti kepercayaan apa saja yang mereka yakini, sedangkan umat Islam akan tetap memeluk agama yang diyakini kebenarannya.

Keyakinan tentang seseorang juga tidak bisa dilihat dari status sosial ataupun pekerjaan mereka, tetap harus kita hormati apapun pekerjaan dan dimana tempatnya. KH. Sholeh Bahruddin menuturkan bahwa baik di pasar, di jalan, di sekolah, baik guru, pedagang, tukang sapu semua adalah saudara. Maksudnya, bahwa siapapun yang kita temui di berbagai tempat maupun profesinya kita tetap harus menghormati dan menganggap mereka semua adalah saudara.

Agree in Disagreement (setuju dalam perbedaan) termasuk salah satu prinsip dalam toleransi. KH. Sholeh Bahruddin setuju dengan hal ini bahkan menganggap bahwa perbedaan adalah hal yang indah sampai-sampai membuat beliau enggan untuk meninggalkan dunia ini. Karena beliau berpandangan bahwa perbedaan merupakan rahmat yang bisa memperkokoh persatuan dan kesatuan. Menurut Umar Hasyim perbedaan tidak harus ada permusuhan karena dengan adanya perbedaan kita harus menyadari adanya keanekaragaman dalam kehidupan ini. Setiap orang pada umumnya yakin bahwa apa yang dianutnya itu adalah paling benar, paling baik, tetapi hal itu tidak menghalangi untuk mengakui kenyataan bahwa kesemuanya itu mempunyai hak hidup dan berkembang. Setuju dalam perbedaan ini bisa

\footnotetext{
${ }^{21}$ Ahmad Nurohim. Pengajian tafsir, ahad 15 april 2012. Minggu, 30 Maret 2014. Diakses 7 Juni 2019

${ }^{22}$ Lihat QS. Al-Baqarah: 256
} 
menimbulkan persaingan sehat yang amat baik bila masing-masing pihak bisa melaksanakan.

Tidak diragukan lagi bahwa Islam sangat menganjurkan sikap toleransi, tolong-menolong, hidup yang harmonis, dan dianmis diantara umat manusia tanpa memandang agama, bahasa, dan ras mereka. ${ }^{23}$ Dan tetap berlaku baik dan adil kepada siapapun selama tidak mengganggu dan melanggar syari'at agama. Hal ini sesuai dengan surat firman Allah dalam Q.S al-Mumtahanah ayat 8-9.

Toleransi dalam pergaulan hidup antar umat beragama yang didasarkan kepada:setiap agama menjadi tanggung jawab pemeluk agama itu sendiri dan mempunyai bentuk ibadat (ritual) dengan sistem dan cara tersendiri yang ditaklifkan (dibebankan) serta menjadi tanggung jawab orang yang memeluknya atas dasar itu, maka toleransi dalam pergaulan hidup antar umat beragama bukanlah toleransi dalam masalah keagamaan,melainkan perwujudan sikap keberagamaan pemeluk suatu agama dalam pergaulan hidup antara orang yang tidak seagama, dalam masalah-masalah kemasyarakatan atau kemaslahatan umum. ${ }^{24}$

Hal inilah yang sudah dipraktikkan oleh KH. Sholeh Bahruddin bahkan sebelum mendirikan pondok pesantren Ngalah. Salah satu contohnya ketika masih di Carat KH. Sholeh Bahruddin memberikan izin dalam pembangunan gereja dan datang pada acara peresmian gereja tersebut. Sama halnya ketika beliau berada di Pandean beliau tetap bersikap luwes dan tidak kaku. Ketika ada acara Natalan di Gereja Tejowangi beliau di undang dan menghadirinya. Kemudian kalau dari agama lain ingin mengadakan kunjungan atau penelitian beliau mempersilahkan dengan senang hati dan tangan terbuka.

Toleransi yang dipraktikkan oleh beliau memang bertujuan untuk mencari maslahat yakni meskipun berbeda agama tetapi tetap bersama-sam menjaga keutuhan NKRI.

Berkumpul dengan orang yang beragama lain bukan berarti kita bebas memaksakan kehendak dalam menentukan ibadah mereka, tetapi kita harus bisa memberi mereka keleluasaan dan kesempatan kepada mereka untuk menjalankan ibadah dan memberikan kebebasan dalam memilih dan berpendapat.

\footnotetext{
${ }^{23}$ Ali Mustafa Yaqub, Toleransi Antar umat Beragama,(Jakarta: Pustaka Firdaus), 2008: 11

${ }^{24}$ Said Aqil: 14
} 
Hal ini dikuatkan dengan adanya prinsip mengenai toleransi antar umat beragama yaitu:

(1) Tidak boleh ada paksaan dalam beragama baik paksaan itu berupa halus maupun dilakukan secara kasar.

(2) Manusia berhak untuk memilih dan memeluk agama yang diyakininya dan beribadat menurut keyakinan itu.

(3) Tidak akan berguna memaksa seseorang agar mengikuti suatu keyakinan tertentu.

(4) Tuhan Yang Maha Esa tidak melarang hidup bermasyarakat dengan yang tidak sefaham atau tidak seagama, dengan harapan menghindari sikap saling bermusuhan. ${ }^{25}$

Bukan hanya menghadiri undangan acara dari agama lain tetapi $\mathrm{KH}$. Sholeh Bahruddin turut mengundang perwakilan dari agama lain dalam acara yang diadakan Universitas Yudharta atau Pondok Pesantren Ngalah yang dihadiri tokoh lintas agama seperti : acara atau kegiatan Kolokium pada tahun 2006, seminar kebangsaan 2010, kunjungan tokoh lintas agama, live e 100 pendeta, kunjungan Jamash gereja Malang jawi wetan, dan masih banyak lagi. ${ }^{26}$

Kegiatan-kegiatan tersebut menunjukkan bahwa KH. Sholeh Bahruddin sangat toleran dan plural dalam mewujudkan Indonesia yang aman dan damai. Mewujudkan kehidupan yang saling menghormati dan menghargai dalam segala perbedaan. Salah satu hasil dari kegiatan tersebut adalah diterbitkannya buku yang berjudul "Serumpun Bambu; Jalan Menuju Kerukunan Sejati". Dalam sambutan buku ini beliau bahwa keberadaan buku ini dimaksudkan untuk menjembatani komunikasi antar agama. Dengan penerbitan buku ini diharapkan dapat dipahami oleh khalayak pembaca yang lebih luas. Mendapatkan inspirasi yang mendalam tentang agama dan keberagaman dalam rangka member makna arti kehidupan, juga menjadi salah satu tujuan dari penerbitan buku ini.

\section{KESIMPULAN}

Toleransi antar sesama meliputi toleransi sesama manusia dan toleransi terhadap makhluk Tuhan lainnya. Toleransi sesama manusia

\footnotetext{
${ }^{25}$ Mohammad Daud Ali.1986. Islam Untuk Disiplin Ilmu Hukum, Sosial dan Politik. Jakarta: CV Wirabuana: 82

${ }^{26}$ Muslim. Wawancara melalui chat whatsApp (13 April 2019)
} 
54 :.: Nilai- Nilai Toleransi Antar Sesama Dan Antar Umat Beragama (Studi Pandangan KH. Sholeh Bahruddin)

ditunjukkan dengan sikap saling menghormati, menghargai, dan saling tolong menolong. Sedangkan toleransi terhadap makhluk Tuhan lainnya meliputi menghargai kehidupan hewan dan juga tumbuhan. Memberi kehidupan yang layak dengan cara merawat dengan baik serta menjaga kebersihan dan kelestarian lingkungan.

Toleransi dalam pergaulan hidup antar umat beragama yang didasarkan kepada: setiap agama menjadi tanggung jawab pemeluk agama itu sendiri dan mempunyai bentuk ibadat (ritual) dengan sistem dan cara tersendiri yang ditaklifkan (dibebankan) serta menjadi tanggung jawab orang yang memeluknya atas dasar itu, maka toleransi dalam pergaulan hidup antar umat beragama bukanlah toleransi dalam masalah keagamaan, melainkan perwujudan sikap keberagamaan pemeluk suatu agama dalam pergaulan hidup antara orang yang tidak seagama, dalam masalah-masalah kemasyarakatan atau kemaslahatan umum.

Menjadikan perbedaan agama sebagai rahmat dengan tidak saling mencaci maki tetapi saling menghormati yang bertujuan untuk menjaga keutuhan NKRI dan kehidupan yang aman dan damai.

\section{DAFTAR PUSTAKA}

Abdullah, Maskuri. 2001. Pluralisme Agama dan Kerukunan dalam Keagamaan. Jakarta. Kompas

Ali, H.M. Daud, dkk. 1989. Islam Untuk Disiplin Ilmu Hukum Sosial dan Politik. Jakarta: Bulan Bintang

Ali , A. Mukti, 1972. Keesaan Tuhan dalam al-Qur'an .Jogjakarta: Yayasan Nida

Ali, Mohammad Daud. 1986. Islam Untuk Disiplin Ilmu Hukum, Sosial dan Politik. Jakarta: CV Wirabuana

Ali Mustafa Yaqub. 2008. Toleransi Antar Umat Beragama. Jakarta: Pustaka Firdaus

Amir, Samsul, Munir. 2009. Ilmu Dakwah. Jakarta: amzah

Anam, Ahmad Muzakkil. Penanaman Nilai-nilai Pendidikan Multikultural di Perguruan Tinggi (Studi Kasus di Universitas Islam Negeri Malang),Unisma, Malang

Aulia, Vivi dan Moh. Yamin. 2011. Meretas Pendidikan Toleransi; Pluralisme dan Multikulturalisme Sebuah Keniscayaan Peradaban. Malang: Madani Media 
Hilmy, Masdar. 2003. Menggagas Paradigma Pendidikan Berbasis Multikulturalisme. Jurnal Ulumuna,Volume VII Edisi 12 Nomor 2

Madjid, Nurcholish. 1993. Islam Kerakyatan dan Keindonesiaan Pemikiran Nurcholis Muda. Bandung: Mizan

Misrawi, Zuhairi. 2007. Al-Qur'an Kitab Toleransi, Inklusivisme, Prulaisme, dan Multikulturalisme. Jakarta: Fitrah

Muhtadin, Ahmad. 2010. "Mutiara Nasihat (Romo KH.M.Sholeh Bahruddin untuk Santri-santrinya)"

Mulyono, Bashori, 2010, Ilmu Perbandingan Agama. Jawa Barat: Pustaka Sayid Sabiq

Munir, Abdul. 1989. Poko-pokok Ajaran NU. Solo: Ramdhani

Nuriz, Adib Fuadi. 2015. Problem Pluralisme Agama dan Dampaknya terhadap

Kehidupan Sosial Keagamaan. Ponorogo: Center for Islamic and Occidental Study.

Pekan Orientasi Antara Umat Beragama Dengan Pemerintah. 1980-1981. 1982. Proyek Pembinaan Kerukunan Hidup Beragama. DepartemenAgama RI: Jakarta

Santri Pondok Pesantren Ngalah. 2013. Ensiklopedi Fiqih Jawabul Masail Bermadzhab Empat : Menjawab Masalah Lokal, Nasional dan Internasional. Pasuruan: Pondok Pesantren Ngalah

Shihab, Quraish. 2012. Tafsir Al-Misbah. Jakarta: Darus Sunnah Press

Shihab ,M. Quraish, 1992. Membumikan al-Qur'an Fungsi dan Peran Wahyu dalam Kehidupan Masyarakat . Bandung:Mizan 